\title{
Effects of the octopus fishery on the American horseshoe crab population in the Ría Lagartos Biosphere Reserve, Mexico
}

\section{Efectos de la pesquería del pulpo sobre la población de la cacerolita de mar en la Reserva de la Biosfera Ría Lagartos, México}

\author{
Juan José Sandoval-Gío ${ }^{1 *}$, Gerardo Avilés-Ramírez², Héctor Javier Ortiz-León ${ }^{3}$, \\ Roberto Zamora-Bustillos ${ }^{4}$, Carmen Olivia Rosas-Correa ${ }^{5}$, José Manuel Castro-Pérez ${ }^{3}$ \\ 1 Tecnológico Nacional de México, Instituto Tecnológico de Tizimín, Final Aeropuerto Cupul, s/n, CP 97700, \\ Tizimín, Yucatán, Mexico. \\ 2 Tecnológico Nacional de México, Instituto Tecnológico de Chiná, Calle 11, s/n entre 22 y 28, CP 24520, \\ Chiná, Campeche, Mexico. \\ 3 Tecnológico Nacional de México, Instituto Tecnológico de Chetumal, Av. Insurgentes, No. 330, Col. Gustavo \\ Gutierrez, CP 77013, Chetumal, Quintana Roo, Mexico. \\ 4 Tecnológico Nacional de México, Instituto Tecnológico de Conkal, Av. Tecnológico, s/n, CP 97345, Conkal, \\ Yucatán, Mexico. \\ ${ }^{5}$ Colegio de la Frontera Sur, Unidad Chetumal, Av. Centenario, km 5.5, CP 77014, Chetumal, Quintana Roo, \\ Mexico. \\ * Corresponding author. E-mail: jsandoval29@hotmail.com
}

\begin{abstract}
The American horseshoe crab, Limulus polyphemus, has been reported to be illegally caught for use as Octopus spp. bait in some localities of the Yucatán Peninsula, Mexico. To learn if the octopus fishery could be negatively influencing the limulus populations in the area, L. polyphemus individuals were sampled twice a year, before and after the annual octopus fishing season, over 4 consecutive years (2015-2018) in Río Lagartos and San Felipe, both in the Ría Lagartos Biosphere Reserve (RLBR), Yucatán. Quadrants were drawn perpendicular to the mangrove edge, physicochemical parameters in the water (depth, temperature, dissolved oxygen, $\mathrm{pH}$, salinity, and electrical conductivity) were determined, and granulometry of marine sediments was measured (Folk technique). The number of live specimens, number of females, and average length were recorded. No significant differences were found for the physicochemical properties of water or the recorded sedimentology $(P>0.05)$. Samplings revealed a low number of organisms per site: 22 in Río Lagartos and 24 in San Felipe, both from data before the start of the 2017 octopus fishing season. In the samplings after the start of the 2018 octopus fishing season, only 2 organisms were observed in Río Lagartos and none in San Felipe. The results showed a significant decrease in the number of live L. polyphemus specimens after the beginning of the octopus fishing season and a decrease in the average length of organisms, suggesting a negative effect of mollusk fishing activities on the horseshoe crab populations. More studies are required that integrate other physicochemical, biological, and socioeconomic factors to elucidate the potential threat of this fishery on L. polyphemus populations in the RLBR.
\end{abstract}

Key words: population dynamics, Limulus polyphemus, mex, Octopus spp., Yucatán Peninsula.

RESUMEN. Se ha documentado que la cacerolita de mar Limulus polyphemus se captura de forma ilegal para uso como carnada de Octopus spp. en algunas localidades de la península de Yucatán, México. Para conocer si la pesquería de pulpo pudiese tener una influencia negativa en las poblaciones de este límulo, se muestrearon organismos de L. polyphemus 2 veces al año, antes y después del comienzo de la temporada anual de pulpo, durante 4 años consecutivos (2015-2018) en Río Lagartos y San Felipe, situados en la Reserva de la Biosfera Ría Lagartos (RBRL), Yucatán. Se trazaron cuadrantes perpendiculares a la vera del manglar y se midieron los parámetros fisicoquímicos del agua (profundidad, temperatura, oxígeno disuelto, $\mathrm{pH}$, salinidad y conductividad eléctrica), así como la granulometría del sedimento marino (mediante el tamizado de Folk). Se registró el número de individuos vivos, el número de hembras y la longitud promedio. No se encontraron diferencias significativas en los parámetros fisicoquímicos del agua ni en la sedimentología registrada $(P>0.05)$. Los muestreos evidenciaron pocos organismos por sitio estudiado: 22 en Río Lagartos y 24 en San Felipe, ambos resultados antes de iniciada la temporada de pulpo de 2017. En los muestreos posteriores al inicio de la temporada de pulpo de 2018, solo se observaron 2 organismos en Río Lagartos y ninguno en San Felipe. Los resultados evidenciaron una disminución significativa en el número de ejemplares vivos de L. polyphemus después de iniciada la temporada de pulpo, así como también una disminución en la longitud promedio de los organismos, lo que sugiere un efecto negativo en las poblaciones de la cacerolita de mar derivado de las actividades propias de la pesca del molusco. Se requieren más estudios que integren otros factores fisicoquímicos, biológicos y socioeconómicos para dilucidar la potencial amenaza de esta pesquería sobre las poblaciones de este límulo en la RBRL.

Palabras clave: dinámica poblacional, Limulus polyphemus, mex, Octopus spp., península de Yucatán. 


\section{INTRODUCTION}

The American horseshoe crab, Limulus polyphemus (Linnaeus, 1758), is an arthropod (class Merostomata, order Xiphosura, family Limulidae) that inhabits 2 defined areas of the American continent, the Atlantic coast of the United States of America (USA) and the Yucatán Peninsula (Mexico), of which in the second it is known as mex (Mayan for spider) (Zaldívar-Rae et al. 2009). The history of life on Earth for this arachnid congener dates back to the Ordovician period, with Lunataspis aurora as the earliest horseshoe crab fossil record and trilobites as their closest evolutionary ancestors (Rudkin and Young 2009). The American horseshoe crab has undergone minimal modifications in its physiognomy since its appearance around 450 million years ago, and it exhibits a solid adaptation to mangroves or beaches with moderate coastal dynamics (Jackson et al. 2002). In these habitats, L. polyphemus feeds on a variety of invertebrates and, because it obtains nutrients through the separation of organic matter, it can be classified as a decomposer; furthermore, in different life stages it is prey to various species of birds, crocodiles, tiger sharks, turtles, raccoons, among others (Walls et al. 2002). Over the past decades, the American horseshoe crab has become relevant in the field of biotechnology because its hemolymph contains limulus amebocyte lysate (LAL), a molecular complex with high economic value used for detecting endotoxin bacterial contamination in the biomedical and pharmacological industry worldwide (Novitsky 1991).

In addition to its evolutionary, ecological, and biotechnological importance, L. polyphemus has been used in the USA for several decades as bait to catch other species of greater importance to fisheries, such as the eel Anguilla rostrata and the sea snails Busycon spp. (Bianchini et al. 1981, Botton and Ropes 1987, Kreamer and Michels 2009). A different situation occurs in Mexico, as L. polyphemus has been documented to be used as bait for Octopus spp. in some localities of the Yucatán Peninsula (Zaldívar-Rae et al. 2009, Munguía-Gil 2010, Salas et al. 2011, Sandoval-Gío et al. 2016, Smith et al. 2017); however, this is an illicit activity because the Official Mexican Norm NOM-059-SEMARNAT-2010 categorizes this species as "endangered" and prohibits its capture (DOF 2010). Furthermore, the International Union for Conservation of Nature has classified L. polyphemus as a "vulnerable species" on its Red List since 2016 and it has emphasized that its populations are gradually declining (Smith et al. 2016).

The octopus fishery is a prominent activity in the Yucatán Peninsula accounting for $80 \%$ of total national production, and Yucatán, the northernmost state in this region, has reported catches of up to $18,000 \mathrm{t}$ per year of 2 species, Octopus vulgaris and Octopus maya (Velázquez-Abunader et al. 2013, Markaida et al. 2019, Sauer et al. 2019). The O. maya fishery produces 15,000 jobs and over 27 million dollars per year in commercial value, with approximately $80 \%$ of catches being exported to Europe and Asia (Jurado-Molina 2010,

\section{INTRODUCCIÓN}

La cacerolita de mar Limulus polyphemus (Linnaeus, 1758) es un artrópodo (clase Merostomata, orden Xiphosura, familia Limulidae) que habita en 2 áreas definidas del continente americano, en la costa atlántica de los Estados Unidos de América (EUA) y en la península de Yucatán (México), de las cuales en la segunda se le conoce como mex (nombre en lengua maya que significa araña) (Zaldívar-Rae et al. 2009). La historia de la vida en la Tierra de este congénere de los arácnidos se remonta al periodo Ordovícico, con Lunataspis aurora como el registro fósil de cacerolitas de mar más antiguo y los trilobites como sus antecesores evolutivos más cercanos (Rudkin y Young 2009). Alrededor de 450 millones de años después de su aparición, la cacerolita de mar ha modificado en forma mínima su fisionomía, y exhibe una sólida adaptación a zonas de manglar o playas de mediana dinámica costera (Jackson et al. 2002). En estos hábitats, L. polyphemus se alimenta de diversos invertebrados $\mathrm{y}$, al obtener nutrientes mediante la separación de materia orgánica, puede catalogarse como especie removedora; además, en sus diferentes estadios de vida, es presa de diversas especies de aves, cocodrilos, tiburones tigre, tortugas, mapaches, entre otros (Walls et al. 2002). En las últimas décadas la relevancia de la cacerolita de mar ha irrumpido en el ámbito biotecnológico, ya que su hemolinfa posee el lisado de amebocitos de limulus (LAL), un complejo molecular útil para la detección de endotoxinas bacterianas contaminantes que tiene un alto valor económico en la industria biomédica y farmacológica a nivel mundial (Novitsky 1991).

Adicional a la importancia evolutiva, ecológica y biotecnológica, en EUA L. polyphemus ha sido utilizada desde hace varias décadas como carnada para la captura de otras especies de mayor importancia pesquera, como la anguila Anguilla rostrata y los caracoles Busycon spp. (Bianchini et al. 1981, Botton y Ropes 1987, Kreamer y Michels 2009). En México, las condiciones son diferentes, pues se ha documentado que $L$. polyphemus ha sido utilizada como carnada para los pulpos Octopus spp. en algunas localidades de la península de Yucatán (Zaldívar-Rae et al. 2009, MunguíaGil 2010, Salas et al. 2011, Sandoval-Gío et al. 2016, Smith et al. 2017); sin embargo, esta actividad es ilícita, ya que la Norma Oficial Mexicana NOM-059-SEMARNAT-2010 categoriza a esta especie como "en peligro de extinción" y prohíbe su captura (DOF 2010). En adición, desde 2016, la Unión Internacional para la Conservación de la Naturaleza ha catalogado a $L$. polyphemus en la Lista Roja como "especie vulnerable" y enfatiza que sus poblaciones están en decremento paulatino (Smith et al. 2016).

La pesquería de pulpo es importante en la península de Yucatán, con una producción que representa el 80\% del total nacional, y en Yucatán, el estado más al norte en esta región, se han reportado capturas de hasta 18,000 t anuales de 2 especies, Octopus vulgaris y Octopus maya (Velázquez-Abunader et al. 2013, Markaida et al. 2019, Sauer et al. 2019). La pesca 
Rosas et al. 2014). The octopus fishing season spans from August 1 to December 15 each year in the Yucatán Peninsula, and significant catches have been recorded in the continental marine zone corresponding to Río Lagartos and San Felipe, the 2 most important ports in the Ría Lagartos Biosphere Reserve (RLBR), a protected natural area in eastern Yucatán (Fig. 1) (Munguía-Gil 2010, Velázquez-Abunader et al. 2013).

Population studies for L. polyphemus in Mexico date back at least 30 years. However, studies identifying illegal catches as one of the main risk factors for this arthropod in the Yucatán Peninsula are new and mention only how fishermen catch American horseshoe crabs, with no details on the number of caught individuals or catch volumes (Salas et al. 2011, Smith et al. 2017). Although the issue is seldom addressed by RLBR residents because they appear to be afraid of identifying those who could be involved in illegal fishing, a recent qualitative study revealed that a significant percentage of the surveyed inhabitants from Río Lagartos and San Felipe (71\%) believe that mex poaching for use as bait in the octopus fishery could threaten the sustainability of L. polyphemus populations in the de O. maya genera 15,000 empleos y un valor comercial de más de 27 millones de dólares al año, y aproximadamente el $80 \%$ de las capturas de esta especie se exporta a Europa y Asia (Jurado-Molina 2010, Rosas et al. 2014). La temporada para la pesca de pulpo en la península de Yucatán se extiende desde el primer día de agosto hasta el 15 de diciembre de cada año, y las capturas significativas se han registrado en la zona marina continental correspondiente a Río Lagartos y San Felipe, los 2 puertos más importantes de la Reserva de la Biosfera de Ría Lagartos (RBRL), un área natural protegida al oriente de Yucatán (Fig. 1) (Munguía-Gil 2010, Velázquez-Abunader et al. 2013).

Los estudios poblacionales de L. polyphemus en México datan de al menos 30 años atrás, pero los estudios que señalan a la captura ilegal de este artrópodo como uno de sus principales riesgos en la península de Yucatán son recientes y, a su vez, solo mencionan la forma en la que los pescadores capturan a las cacerolitas, sin detallar la cantidad de individuos atrapados o el volumen de captura realizado (Salas et al. 2011, Smith et al. 2017). Aunque el tema es poco abordado

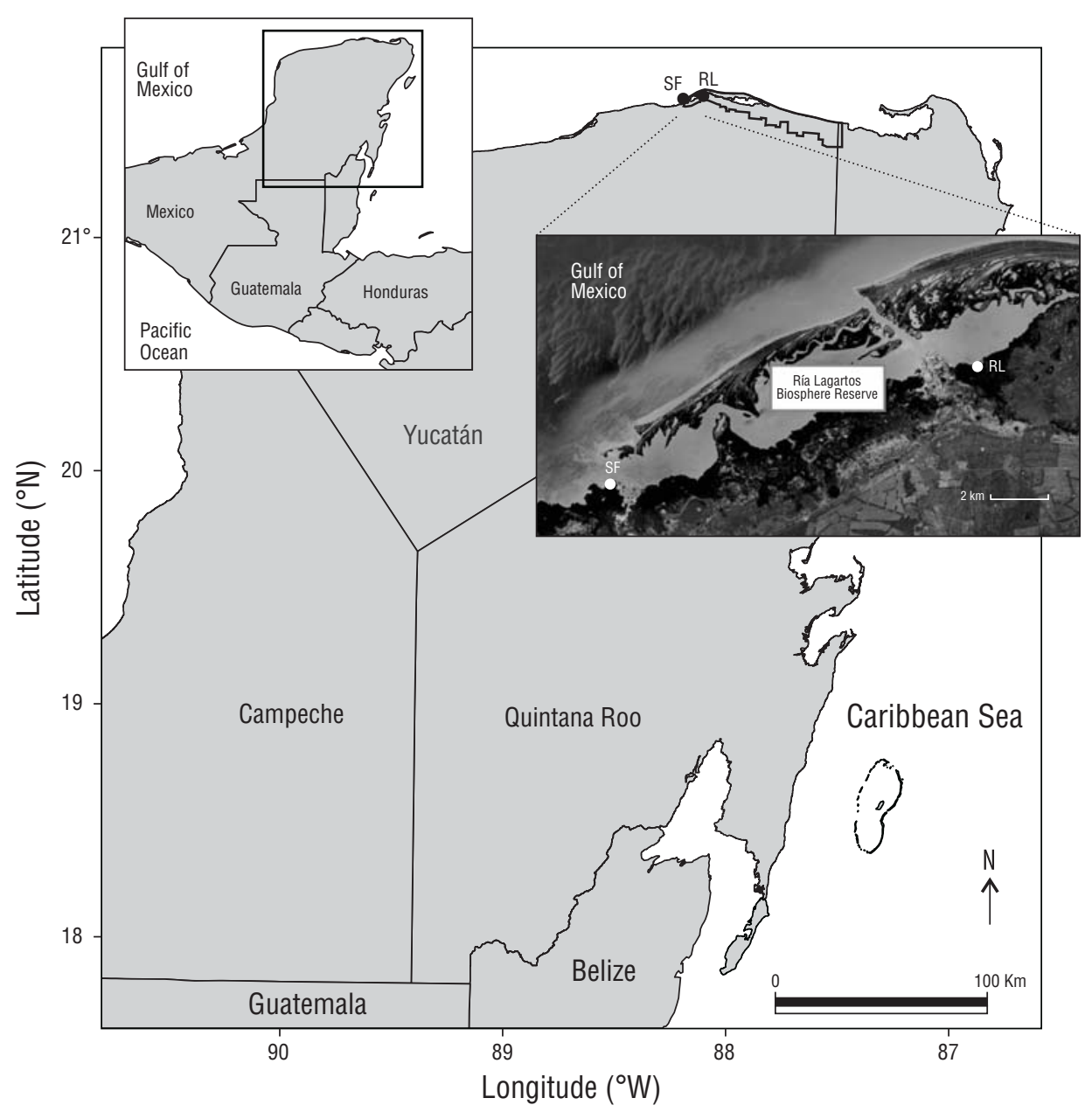

Figure 1. San Felipe (SF) and Río Lagartos (RL) in the Ría Lagartos Biosphere Reserve (solid outline), Yucatán, Mexico.

Figura 1. San Felipe (SF) y Río Lagartos (RL) en la Reserva de la Biosfera Ría Lagartos (línea continua), Yucatán, México. 
RLBR area (Sandoval-Gío et al. 2016). In the ecological context, a limitation to knowing whether this illegal extraction is quantitatively affecting $L$. polyphemus populations in the Yucatán Peninsula is the fact that studies addressing seasonal population trends have been discontinuous and have therefore not offered precise data on the demographic behavior of this species (Gómez-Aguirre 1993, Gómez-Aguirre and Yáñez-Martínez 1995, Ortiz-León and Rosas-Correa 2011, Rosas-Correa and Ortiz-León 2012).

Regarding the ethology of the species, the American horseshoe crab in the Yucatán Peninsula is known to reproduce yearround (Smith et al. 2017), with presence of nests in the RLBR in spring and summer (Sandoval-Gío et al. 2018), partly coinciding with the start of the octopus fishing season on the first day of August. Governed by the lunar cycles, L. polyphemus migrates from deep waters to estuaries to spawn. During the high tide, on nights with a full moon, the male and female, in amplexus, head to the high water line, where the female digs nests and lays numerous eggs that the male then fertilizes; the eggs are covered in substrate by wave action and become exposed the following lunar cycle, when swimming trilobite larvae hatch (Ortiz-León and Rosas-Correa 2011).

The Guiding Plan for the Sustainable Development of Fisheries and Aquaculture in Yucatán states that, in order to guarantee the sustainability of ecosystems and fishery resources, appropriate bioecological data that help determine the anthropogenic influence on those resources must be provided, especially if those resources are potentially threatened (Flores-Nava et al. 2016). In this context, this study was carried out in the 2 most important communities of the RLBR, Río Lagartos and San Felipe, where 2 conditions of interest converge: (1) the reported abundance of L. polyphemus is among the most important in Yucatán and (2) the octopus season is very active, with indications of illegal use of American horseshoe crab as bait. Thus, to know what effect the octopus fishery has on the L. polyphemus population, samplings were carried out over 4 consecutive years $(2015,2016$, 2017, and 2018) at 2 specific times each year: the first a few weeks before the octopus season began and the second a few weeks after this season began. Our hypothesis states that significant decreases in parameters such as the number of individuals, number of females, and average length of L. polyphemus occurring after the start of the octopus season could be indicators of this fishery representing a risk for the American horseshoe crab populations in these 2 localities of the RLBR. The obtained results will contribute to establish sustainable fishery management plans and conservation programs for L. polyphemus in Mexico.

\section{MATERIALS AND METHODS}

The study was carried out in the localities of Chiquilá, in Río Lagartos $\left(21^{\circ} 35.805^{\prime} \mathrm{N}, 88^{\circ} 87.410^{\prime} \mathrm{W}\right)$, and Punta Morena, in San Felipe $\left(21^{\circ} 34.102^{\prime}\right.$ N, $88^{\circ} 14.224^{\prime}$ W), both in the RLBR, Yucatán, Mexico (Fig. 1), during the 2015, 2016, por los pobladores de la RBRL por un aparente temor a señalar quiénes estarían involucrados en la pesca ilícita, un estudio cualitativo reciente reveló que un porcentaje importante de los habitantes de Río Lagartos y San Felipe encuestados $(71 \%)$ opina que la pesca furtiva del mex para uso como carnada en la pesquería de pulpo podría significar una amenaza para el mantenimiento de las poblaciones de L. polyphemus en la zona de la RBRL (Sandoval-Gío et al. 2016). En el contexto ecológico, una limitante para conocer si esta captura ilegal estuviese afectando cuantitativamente a las poblaciones de L. polyphemus en la península de Yucatán es el hecho de que los estudios sobre la tendencia temporal de sus poblaciones han sido discontinuos y, por tanto, no han ofrecido un conocimiento preciso sobre el comportamiento demográfico de esta especie (Gómez-Aguirre 1993, GómezAguirre y Yáñez-Martínez 1995, Ortiz-León y Rosas-Correa 2011, Rosas-Correa y Ortiz-León 2012).

Sobre la etología de la especie, se sabe que la cacerolita de mar en la península de Yucatán se reproduce durante todo el año (Smith et al. 2017), con presencia de nidos en la RBRL en la primavera y el verano (Sandoval-Gío et al. 2018), temporadas que coinciden, en parte, con la apertura de la temporada de pesca de pulpo el primer día de agosto. Regida por los ciclos lunares, L. polyphemus migra de aguas profundas hacia los esteros para desovar. Durante la marea alta, en noches de luna llena, el macho y la hembra, en amplexo, se dirigen a la línea de pleamar, donde la hembra cava nidos y deposita numerosos huevos que el macho fertiliza; los huevos se cubren de sustrato por la acción del oleaje y quedan al descubierto en el siguiente ciclo lunar, cuando eclosionan larvas trilobitas nadadoras (Ortiz-León y Rosas-Correa 2011).

El Plan Rector de Acuacultura y Pesca Sustentable de Yucatán señala que, para garantizar la sostenibilidad de los ecosistemas y de los recursos asociados a la pesca, deben proveerse datos bioecológicos oportunos que establezcan la influencia antropogénica sobre esos recursos, especialmente si están potencialmente amenazados (Flores-Nava et al. 2016). En este contexto, se realizó este estudio en las 2 comunidades más importantes de la RBRL, Río Lagartos y San Felipe, porque ahí confluyen 2 condiciones de interés: (1) la abundancia de L. polyphemus registrada es de las más importantes en Yucatán y (2) la temporada de pulpo es muy activa, con indicios del uso ilegal de la cacerolita de mar como carnada. Así, para conocer el efecto de la pesquería de pulpo en la población de L. polyphemus, se realizaron muestreos durante 4 años seguidos (2015, 2016, 2017 y 2018), en 2 momentos puntuales de cada año: el primero unas semanas antes de que comenzara la temporada de pulpo y el segundo unas semanas después que esta temporada iniciara. Se plantea la hipótesis de que las disminuciones significativas en parámetros como el número de individuos, el número de hembras y la longitud promedio de $L$. polyphemus después de iniciada la temporada de pulpo podrían ser indicadores de que esta pesquería represente un riesgo para las poblaciones de cacerolita de mar 
2017, and 2018 rainy seasons (May to September). The predominant weather in the RLBR is $A w_{o}\left(x^{\prime}\right)$ (Köppen, modified by García 2004), with annual rainfall averaging $669.9 \mathrm{~mm}$ (CONAGUA 2017).

Two samplings were carried out each year. The first sampling was done before the octopus season started and the second after the start of this season (Table 1). Considering the ethology of the species, samplings were done in a single night with a single replica during nights with full moon or nights closest to this lunar phase to allow sighting the largest number of individuals upon their arrival onshore en masse.

Sampling stations were chosen at random in 2015, and the geographic location of each station was recorded with a Garmin Etrex 30 GPS. Samplings in 2016, 2017, and 2018 were conducted at the same locations. A $10 \times 100 \mathrm{~m}$ $\left(1,000 \mathrm{~m}^{2}\right)$ transect was set at each of the sampling stations, which were all located in coastline areas with mangrove vegetation. At each sampling point, triplicate measurements were taken of depth, using a lead line graduated in centimeters, and the physicochemical parameters (namely, temperature, dissolved oxygen, $\mathrm{pH}$, and conductivity), using a $\mathrm{HACH}$ multiparameter sonde. Marine sediment was obtained using a corer made out of a PVC tube measuring $40 \mathrm{~cm}$ long and $5 \mathrm{~cm}$ in diameter, and samples were placed in labeled resealable $18 \times 20$-cm Ziplock plastic bags. Sediment samples were taken to the laboratory at the Technological Institute of Chiná, Campeche, Mexico, for a granulometric analysis using the Folk mechanical sieving method (Folk 1966).

Of the live specimens, morphometric data were collected using a vernier caliper $(\mathrm{mm})$ along the longitudinal section, that is, measurements of the length of the prosoma, which is the anterior region of chelicerates; the opisthosoma, which is the middle part; and the telson, which is the posterior region. Total length (TL) was determined by the sum of these 3 measurements: $\mathrm{TL}=$ prosoma + opisthosoma + telson. Each sampled individual was also weighed (g) with an OHAUS digital balance with $0.1 \mathrm{~g}$ precision. The sex of live specimens was determined by the shape of the pedipalps, and sexual maturity was estimated from the width of the prosoma. After this, the specimens were released. The General Directorate of Wildlife authorized sampling through licenses SGPA/ DGVS/10056/15 and SGPA/DGVS/002163/18.

The data for the physicochemical parameters of water and the average lengths of organisms were subjected to a one-way analysis of variance (ANOVA), with the Tukey post-hoc test, to assess the difference between means $(P>0.05)$ using GraphPad Prism v.7.0 (GraphPad Software, USA). GRADISTAT (Kenneth Pye Associates, United Kingdom) was used to analyze the main sedimentological characteristics (phi, classification, symmetry, and type of curve). The abundance of organisms found during each sampling at both locations was analyzed using a chi-square test with a $95 \%$ confidence level to distinguish differences between the number of organisms observed before and after the start of the octopus season for each year (2015-2018). en estas 2 localidades de la RBRL. Los resultados obtenidos contribuirán a establecer planes de manejo pesquero sostenible y programas de conservación de L. polyphemus en México.

\section{MATERIALES Y MÉTOdOS}

El estudio se realizó en las localidades de Chiquilá, en Río Lagartos $\left(21^{\circ} 35.805^{\prime} \mathrm{N}, 88^{\circ} 87.410^{\prime} \mathrm{W}\right)$, y punta Morena, en San Felipe ( $21^{\circ} 34.102^{\prime}$ N, $88^{\circ} 14.224^{\prime}$ W), ambas pertenecientes a la RBRL, Yucatán, México (Fig. 1), en las temporadas climáticas de lluvias (mayo a septiembre) de 2015, 2016, 2017 y 2018. El clima predominante en la RBRL es $A w_{o}\left(x^{\prime}\right)$ (Köppen, modificado por García 2004), con una precipitación pluvial anual promedio de $669.9 \mathrm{~mm}$ (CONAGUA 2017).

Se llevaron a cabo 2 muestreos al año. El primer muestreo se realizó antes de iniciada la temporada de pulpo y el segundo, después de iniciada esta temporada (Tabla 1). Los muestreos se realizaron en una sola noche con una sola réplica, y coincidieron con las noches de luna llena o lo más cerca a esta fase lunar para, con base en la etología de la especie, realizar la observación del mayor número de individuos captados en arribazón.

Las estaciones de muestreo fueron elegidas al azar en 2015, y la ubicación geográfica de cada una fue registrada con un geoposicionador Garmin Etrex 30. Los muestreos en 2016, 2017 y 2018 se llevaron a cabo en las mismas ubicaciones. En cada una de las estaciones, todas ubicadas en zonas de línea de costa con vegetación de manglar, se colocó un transecto de $10 \times 100 \mathrm{~m}\left(1,000 \mathrm{~m}^{2}\right)$. En cada punto de muestreo se registraron, por triplicado, la profundidad, con una sondaleza graduada en centímetros, y los parámetros fisicoquímicos temperatura, oxígeno disuelto, $\mathrm{pH}$ y conductividad, con una sonda multiparamétrica $\mathrm{HACH}$. El sedimento marino se obtuvo con la ayuda de un nucleador hecho a base de un tubo de PVC de $40 \mathrm{~cm}$ de largo y $5 \mathrm{~cm}$ de diámetro, y se depositó en bolsas de plástico resellables Ziplock de $18 \times 20 \mathrm{~cm}$ etiquetadas. Las muestras de sedimento se transportaron al laboratorio del Instituto Tecnológico de Chiná, Campeche, México, para un análisis granulométrico mediante la técnica del tamizado mecánico de Folk (Folk 1966).

De los ejemplares vivos, se registraron los datos morfométricos con un vernier $(\mathrm{mm})$ en sección longitudinal, es decir, la longitud del prosoma, que es la región anterior de los quelicerados; del opistosoma, que es la parte media; y del telson, que es la región posterior. Con la suma de estas 3 mediciones se determinó la longitud total (LT): $\mathrm{LT}=$ prosoma + opistosoma + telson. Cada individuo recolectado también fue pesado $(\mathrm{g})$ con una balanza digital OHAUS con precisión de $0.1 \mathrm{~g}$. El sexo de los ejemplares vivos se determinó de acuerdo con la forma de los pedipalpos, y la madurez sexual se estimó a partir del ancho del prosoma. Posterior a esto, los ejemplares fueron liberados. La recolecta fue autorizada por la Dirección General de Vida Silvestre mediante las licencias SGPA/DGVS/10056/15 y SGPA/DGVS/002163/18. 


\section{RESULTS}

No significant differences in the physicochemical parameters of water were found between sampling years at each locality or between localities $(P>0.05)$ (see global results in Table 2). The granulometric analysis showed no significant differences either. Specifically, sediment in Río Lagartos consisted of $94.66 \%( \pm 2.08)$ sand and $5.33 \%( \pm 2.08)$ silt. In addition, sedimentology showed poorly graded medium sand, with an almost symmetrical and highly platykurtic curve. In San Felipe, the percentage of sand was also the most prominent $(95.00 \% \pm 2.00)$ and that of silt was low $(5.00 \% \pm 2.00)$. Sedimentology there showed poorly graded medium sand, with an asymmetric and leptokurtic curve.

During the 2015-2018 period, the abundance of live L. polyphemus individuals varied from 10 to 21 specimens in Río Lagartos and from 9 to 24 in San Felipe before the octopus season (Fig. 2). The number of live L. polyphemus specimens decreased in both localities after the beginning of the octopus season each year. For 2015, the number of organisms found before and after the octopus season in both localities did not differ $\left(\chi^{2}=3.000<3.845\right.$; d.f. $\left.=1, P<0.05\right)$. For 2016, 2017, and 2018, the number of organisms found at Río Lagartos and San Felipe before and after the octopus season did change significantly $\left(\chi^{2}=6.916>3.845, \chi^{2}=30.175>3.845\right.$, $\chi^{2}=22.000>3.845$, respectively) (d.f. $=1, P<0.05$ ).

The analysis of average TL for $L$. polyphemus individuals by locality showed significant differences, with larger specimens being observed at both localities before the octopus fishing season $(P<0.05)$ (Fig. 3a, b ). For the analysis of average L. polyphemus lengths by year, ANOVA also showed significant differences, with the highest values before the octopus fishing season $(P<0.05)$. The highest average length (306 $\mathrm{mm}$ ) was recorded during the sampling done before the start of the 2017 octopus season (Fig. 3a, b).

\section{Discussion}

Río Lagartos and San Felipe, in the RLBR, have been reported as aggregation and reproduction sites for
Los datos de los parámetros físicoquímicos del agua y las longitudes promedio de los organismos se sometieron a un análisis de varianza de una vía (ANDEVA), con la prueba post-hoc de Tukey, para evaluar la diferencia entre medias $(P>0.05)$ utilizando el programa estadístico GraphPad Prism v.7.0 (GraphPad Software, EUA). Para analizar los principales valores sedimentológicos (phi, clasificación, simetría y tipo de curva), se utilizó el programa estadístico GRADISTAT (Kenneth Pye Associates, Reino Unido). La abundancia de organismos encontrados en cada muestreo en ambas localidades, se analizó mediante una prueba de chi cuadrada con un nivel de confianza del $95 \%$ para distinguir diferencias entre el número de organismos observados antes y después de iniciada la temporada de pulpo de cada año (2015-2018).

\section{Resultados}

No se encontraron diferencias significativas en los parámetros físicoquímicos del agua entre los años de muestreo en cada localidad ni entre localidades $(P>0.05)$ (ver resultados globales en Tabla 2). El análisis granulométrico tampoco mostró diferencias significativas. Específicamente, se encontró que el sedimento en Río Lagartos estuvo conformado por un $94.66 \%( \pm 2.08)$ de arena y un $5.33 \%( \pm 2.08)$ de limo. Además, la sedimentología evidenció arena media pobremente clasificada, con una curva casi simétrica y muy platicúrtica. En San Felipe, el porcentaje de arena también fue el más predominante $(95.00 \% \pm 2.00)$ y el de limo fue bajo $(5.00 \% \pm 2.00)$. La sedimentología ahí evidenció arena media pobremente clasificada, con una curva asimétrica y leptocúrtica.

Durante el periodo 2015-2018, la abundancia de organismos vivos de $L$. polyphemus varió de 10 a 21 ejemplares en Río Lagartos y de 9 a 24 en San Felipe antes de la temporada de pulpo (Fig. 2). Se observaron disminuciones en el número de ejemplares vivos de L. polyphemus en ambas localidades después del inicio de la temporada de pulpo en cada año. Para 2015, no se encontraron diferencias entre el número de organismos encontrados antes y después de la temporada de pulpo en ambas localidades $\left(\chi^{2}=3.000<3.845\right.$; g.l. $=1$,

Table 1. Localities and dates for Limulus polyphemus samplings carried out in the Ría Lagartos Biosphere Reserve, Yucatán, Mexico, before and after the octopus fishing season.

Tabla 1. Localidades y fechas de los muestreos de Limulus polyphemus realizados en la Reserva de la Biosfera Ría Lagartos, Yucatán, México, antes y después de la temporada de pesca de pulpo.

\begin{tabular}{llllll}
\hline & & \multicolumn{4}{c}{ Year } \\
\cline { 3 - 5 } Locality & Sampling & \multicolumn{1}{c}{2015} & 2016 & \multicolumn{1}{c}{2017} & \multicolumn{2}{c}{2018} \\
\hline Río Lagartos & Before & 29 May & 28 May & 17 May & 31 May \\
& After & 30 August & 28 August & 17 September & 21 September \\
San Felipe & Before & 30 May & 14 May & 16 May & 31 May \\
& After & 29 August & 30 August & 16 September & 16 September \\
\hline
\end{tabular}


Table 2. Physicochemical (mean \pm standard deviation) properties of water in the 2 localities were Limulus polyphemus was sampled (2015-2018).

Tabla 2. Parámetros físicoquímicos (promedio \pm desviación estándar) del agua en las 2 localidades donde se muestreó Limulus polyphemus (2015-2018).

\begin{tabular}{lccccc}
\hline Locality & $\begin{array}{c}\text { Depth } \\
(\mathrm{m})\end{array}$ & $\begin{array}{c}\text { Temperature } \\
\left({ }^{\circ} \mathrm{C}\right)\end{array}$ & $\begin{array}{c}\text { Dissolved oxygen } \\
\left(\mathrm{mg} \cdot \mathrm{L}^{-1}\right)\end{array}$ & $\mathrm{pH}$ & $\begin{array}{c}\text { Conductivity } \\
\left(\mathrm{mS} \cdot \mathrm{cm}^{-1}\right)\end{array}$ \\
\hline Río Lagartos & $0.85 \pm 0.02$ & $30.06 \pm 0.30$ & $6.73 \pm 0.06$ & $7.93 \pm 0.05$ & $57.45 \pm 0.45$ \\
San Felipe & $0.86 \pm 0.04$ & $30.42 \pm 0.10$ & $6.79 \pm 0.04$ & $7.91 \pm 0.07$ & $57.23 \pm 0.37$ \\
\hline
\end{tabular}

L. polyphemus in Mexico (Zaldívar-Rae et al. 2009, Sandoval-Gío et al. 2018), but quantitative records of populations of this species have not been continuously documented. The present study represents the first attempt in Mexican territory to assess L. polyphemus in a specific area and season for 4 consecutive years (2015-2018), and the obtained results can therefore provide a helpful overview of the populations. Recording data before and after the start of the octopus season in the 2 most important localities of the RLBR can particularly reveal the local impact of this fishery on the demographic dynamics of the American horseshoe crab inhabiting this protected natural area.

The present investigation showed that in the 4 consecutive sampling years at Río Lagartos and San Felipe, L. polyphemus counts markedly decreased after the start of the octopus season at both study sites, suggesting that this mollusk fishery has a negative impact on limulus populations. The results of the chi square analysis indicated population abundances were different between 2016, 2017, and 2018 , that is, that the number of organisms decreased significantly due to the illegal extraction of organisms for use as octopus bait.

Different risk factors have been posed as causes of L. polyphemus population declines in the Yucatán Peninsula, notably habitat loss, pollution, and poaching (Zaldívar-Rae et al. 2009, Smith et al. 2017). In the RLBR, even under the environmental protection status granted to L. polyphemus, as it is an endangered species, illegal catches for use as bait in the octopus fishery have been disclosed (Salas et al. 2011, Sandoval-Gío et al. 2016, Smith et al. 2017). A recent study determined that a significant percentage (70.67\%) of Río Lagartos and San Felipe inhabitants maintain that L. polyphemus poaching could be the main threat driving population declines for this species, outweighing habitat alteration on the coastline or pollution (Sandoval-Gio et al. 2016). Other studies have reported that this species is used as octopus bait when the traditional baits, namely the Florida stone crab (Menippe mercenaria) and the longnose spider crab (Libinia dubia), go scarce (Salas et al. 2011, Smith et al. 2017, Markaida et al. 2019).

The first studies on the population dynamics of the American horseshoe crab in coastal areas on the Yucatán Peninsula were carried out between the mid-1980s and mid-1990s, reporting a declining trend in the number
$P<0.05)$. Para 2016, 2017 y 2018, el número de organismos encontrados en Río Lagartos y San Felipe antes y después de la temporada de pulpo sí fue significativamente diferente $\left(\chi^{2}=6.916>3.845, \chi^{2}=30.175>3.845, \chi^{2}=22.000>3.845\right.$, respectivamente) (g.l. $=1, P<0.05)$.

En cuanto al análisis de la LT promedio de los individuos de L. polyphemus por localidad, se observaron diferencias significativas, con ejemplares de mayor tamaño en ambas localidades antes de la temporada de pesca de pulpo $(P<0.05)$ (Fig. 3a, b). Para el análisis anual de las longitudes promedio de L. polyphemus, el ANDEVA también mostró diferencias significativas, con los valores más altos antes de la temporada de pesca de pulpo $(P<0.05)$. El registro más alto de la longitud promedio (306 $\mathrm{mm}$ ) correspondió al muestreo realizado antes de que iniciara la temporada de pulpo de 2017 (Fig. 3a, b).

\section{Discusión}

Río Lagartos y San Felipe, en la RBRL, se han reportado como sitios de agregación y reproducción de $L$. polyphemus en México (Zaldívar-Rae et al. 2009, Sandoval-Gío et al. 2018), pero no se han documentado continuamente registros cuantitativos de las poblaciones de esta especie. Así, el presente estudio representa el primer esfuerzo en territorio mexicano para evaluar a $L$. polyphemus en una misma zona y temporada durante 4 años consecutivos (2015-2018), por lo que los resultados obtenidos pueden ofrecer un panorama poblacional de utilidad. En especial, al registrar datos previos y posteriores al inicio de la temporada de pulpo en las 2 localidades más importantes de la RBRL, se puede revelar el impacto local de esta pesquería en la demografía de la cacerolita de mar que habita esta área natural protegida.

En la presente investigación, se evidenció que en los 4 años consecutivos de muestreos en Río Lagartos y San Felipe, tras el inicio de la temporada de pulpo, los conteos de L. polyphemus disminuyeron notoriamente en los 2 sitios evaluados, lo cual sugiere un efecto negativo de la pesquería del molusco en la población del límulo. Los resultados del análisis de chi cuadrada indicaron que sí existieron diferencias en la abundancia de la población entre los años 2016, 2017 y 2018, es decir, que el número de organismos disminuyó significativamente por efecto de la extracción ilegal de organismos para su uso como carnada para pulpo. 

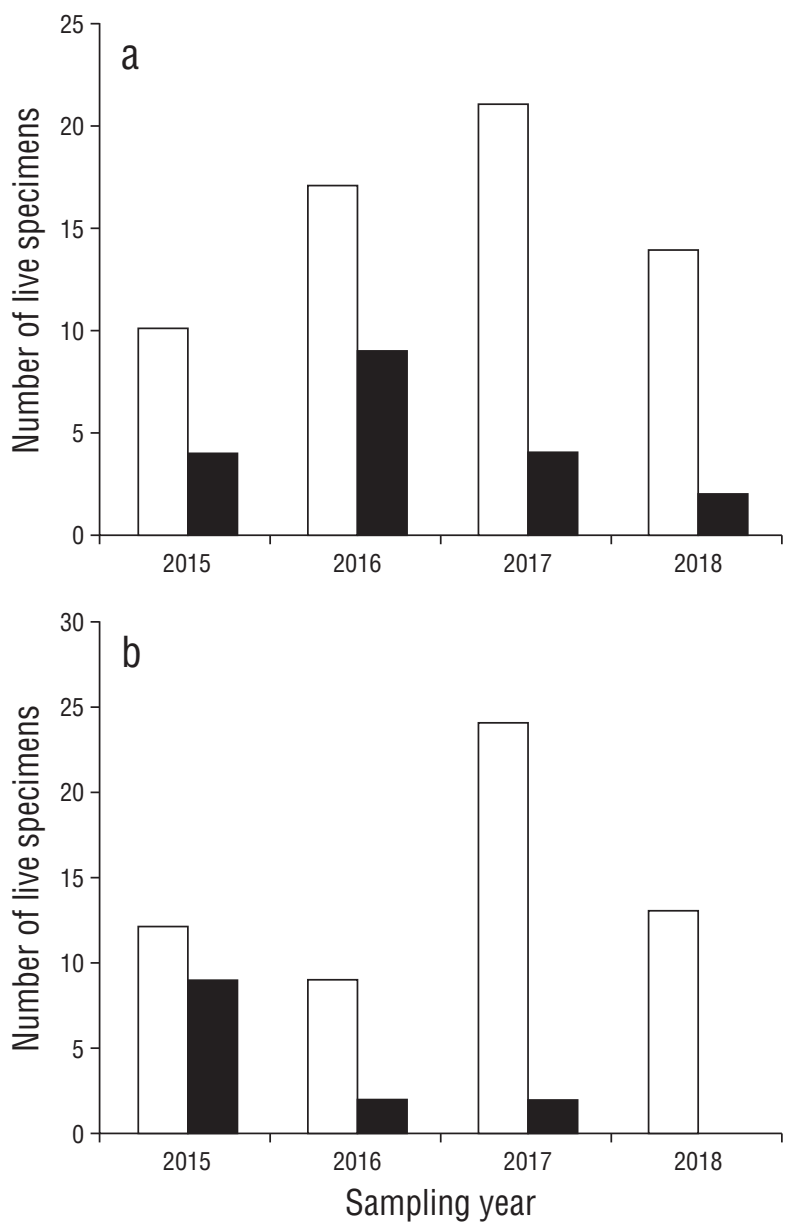

Figure 2. Number of live Limulus polyphemus specimens found at Río Lagartos (a) and San Felipe (b), Yucatán, Mexico, in the period from 2015 to 2018. White bars: before the octopus fishing season. Black bars: during the octopus fishing season.

Figura 2. Número de especímenes vivos de Limulus polyphemus encontrados en Río Lagartos (a) y San Felipe (b), Yucatán, México, en el periodo de 2015 a 2018. Barras blancas: antes de la temporada de pesca de pulpo. Barras negras: durante la temporada de pesca del pulpo.

of individuals in the areas with greatest anthropogenic disturbance (Gómez-Aguirre 1993, Gómez-Aguirre and Yáñez-Martínez 1995). Gómez-Aguirre (1994) found 63 L. polyphemus individuals, including adults and juveniles, at Río Lagartos in 1985 but found less than 20 live specimens in this same locality 9 years later. Two studies on Holbox Island, an area adjacent to the RLBR, covering the 3 climatic seasons in the region (dry, rainy, and northerly winds) recorded a total of 331 (Ortiz-León and Rosas-Correa 2011) and 695 (RosasCorrea and Ortiz-León 2012) L. polyphemus individuals, with a maximum of $30.5 \%$ of individuals being live organisms, revealing that the American horseshoe crab population was scarce. García-Bielma (2011) monitored the population in Términos Lagoon, Campeche, and found a stable trend in the number of organisms, however, noting negative aspects
Diversos factores de riesgo se han planteado como causantes de la disminución de las poblaciones de L. polyphemus en la península de Yucatán, especialmente la pérdida del hábitat, la contaminación y la pesca furtiva (Zaldívar-Rae et al. 2009, Smith et al. 2017). En la RBRL, aún bajo el estado de protección ambiental que se le confiere a L. polyphemus como especie en peligro de extinción, se ha revelado su captura ilegal para uso como carnada en la pesquería de pulpo (Salas et al. 2011, Sandoval-Gío et al. 2016, Smith et al. 2017). Un estudio reciente ha asentado que un porcentaje significativo $(70.67 \%)$ de pobladores de Río Lagartos y San Felipe afirma que la pesca furtiva de L. polyphemus pudiese ser la principal amenaza de disminución poblacional para la especie, por encima de la alteración de la línea de costa del hábitat o la contaminación (Sandoval-Gio et al. 2016). Otras investigaciones han documentado que esta especie se utiliza como carnada para pulpo cuando escasean los cebos tradicionales, que son el cangrejo moro (Menippe mercenaria) y el cangrejo araña Libinia dubia (Salas et al. 2011, Smith et al. 2017, Markaida et al. 2019).

Entre mediados de la década de 1980 y de la década de 1990 se llevaron a cabo los primeros estudios sobre la dinámica poblacional de la cacerolita de mar en localidades costeras de la península de Yucatán, los cuales registraron un número de ejemplares tendiente a la baja en las áreas de mayor perturbación antropogénica (Gómez-Aguirre 1993, Gómez-Aguirre y Yáñez-Martínez 1995). Gómez-Aguirre (1994) encontró 63 organismos, adultos y juveniles, de L. polyphemus en Río Lagartos en 1985, pero encontró menos de 20 ejemplares vivos en esta misma localidad 9 años más tarde. Dos estudios en la isla de Holbox, área colindante con la RBRL, que abarcaron las 3 temporadas climáticas de la región (secas, lluvias y nortes), registraron en total 331 (Ortiz-León y Rosas-Correa 2011) y 695 (Rosas-Correa y Ortiz-León 2012) individuos de L. polyphemus y, de éstos, un máximo del $30.5 \%$ de organismos estaban vivos, lo que reveló que la población de la cacerolita de mar era escasa. García-Bielma (2011) realizó un monitoreo poblacional en la laguna de Términos, Campeche, y encontró una tendencia estable en el número de organismos, pero con aspectos negativos que pudiesen amenazar dicha estabilidad, como cambios en la línea de costa, contaminación del hábitat y pesca accidental por el arrastre de redes, aunque no incluyó a la pesquería de pulpo como factor de riesgo. En la presente investigación, realizada en la temporada de lluvias, los resultados revelaron un número reducido de organismos por sitio estudiado (máximo de 21 en Río Lagartos y 24 en San Felipe, ambos previo a la temporada de pulpo de 2017). En los muestreos posteriores al inicio de la temporada de pulpo, los conteos disminuyeron drásticamente: en 2018 se observaron solo 2 organismos en Río Lagartos y ninguno en San Felipe.

Cabe destacar que los parámetros fisicoquímicos del agua y la textura del sedimento no variaron significativamente por localidad durante el presente estudio. Los datos de estos parámetros fueron similares a los registrados previamente (Sandoval-Gío et al. 2018), por lo que podría descartarse una 
that could threaten this stability, such as changes to the coastline, habitat pollution, and trawl net bycatch; the study did not identify the octopus fishery as a risk factor. The present study, carried out during the rainy season, revealed a low number of organisms per study site (maximum of 21 in Río Lagartos and 24 in San Felipe, both prior to the 2017 octopus season). In the samplings after the start of the octopus season, the counts drastically decreased: only 2 organisms were observed in 2018 in Río Lagartos and none in San Felipe.

It should be noted that the physicochemical parameters of water and sediment texture did not vary significantly between localities during the present study. Data for these parameters were similar to those in previous reports (Sandoval-Gío et al. 2018) and so the physicochemical composition of water and the composition of sediments can be discarded as factors having a negative influence on the low number of American horseshoe crabs found in the study.

In the present study, in addition to observing a decrease in the number of L. polyphemus individuals, the mean TL of sampled individuals decreased after the octopus fishing season started. Maximum values reached a global average (2015-2018) of $280 \mathrm{~mm}$ in San Felipe (before the octopus season) (Fig. 3a); the maximum average length was $\sim 300 \mathrm{~mm}$ before the 2017 octopus season (Fig. 3b). In contrast, TL values during the octopus season did not exceed $260 \mathrm{~mm}$. In the individual count, the 2 specimens with the largest TL measured 400 and $429 \mathrm{~mm}$, and both were collected during the samplings conducted before the octopus season in Río Lagartos in 2015 and 2017, respectively (data not shown). Regarding these records, other authors have reported similar sizes in previous studies carried out in the Yucatán Peninsula (Ortiz-León and Rosas-Correa 2011, Rosas-Correa and Ortiz-León 2012).

In L. polyphemus, as in other species, size and weight increase with age (Vijayakumar et al. 2000). The results of the present study show a decrease in average TL after the start of the octopus season, suggesting that in the context of the illegal supply of $L$. polyphemus to the octopus fishery, poachers could be extracting the largest and therefore oldest individuals to profit from more flesh. The predilection of poachers for larger organisms could have several negative implications for the American horseshoe crab, especially in terms of reproduction and spawning, since the largest American horseshoe crabs are normally females (Smith et al. al. 2017). During most of our samplings, we found fewer females during the octopus season than before it started; however, this trend was more evident in Río Lagartos but not in San Felipe (data not shown).

On another note, it is important to emphasize that we cannot dismiss the fact that other factors from the life history of the species, for example, migration, recruitment, reproductive season, or natural mortality, could be causing the observed changes in the size of the American horseshoe crabs. However, biological studies in the study area to date are insufficient. Swan (2005) studied the migration of L. polyphemus in the North Atlantic coast of the USA and found that a
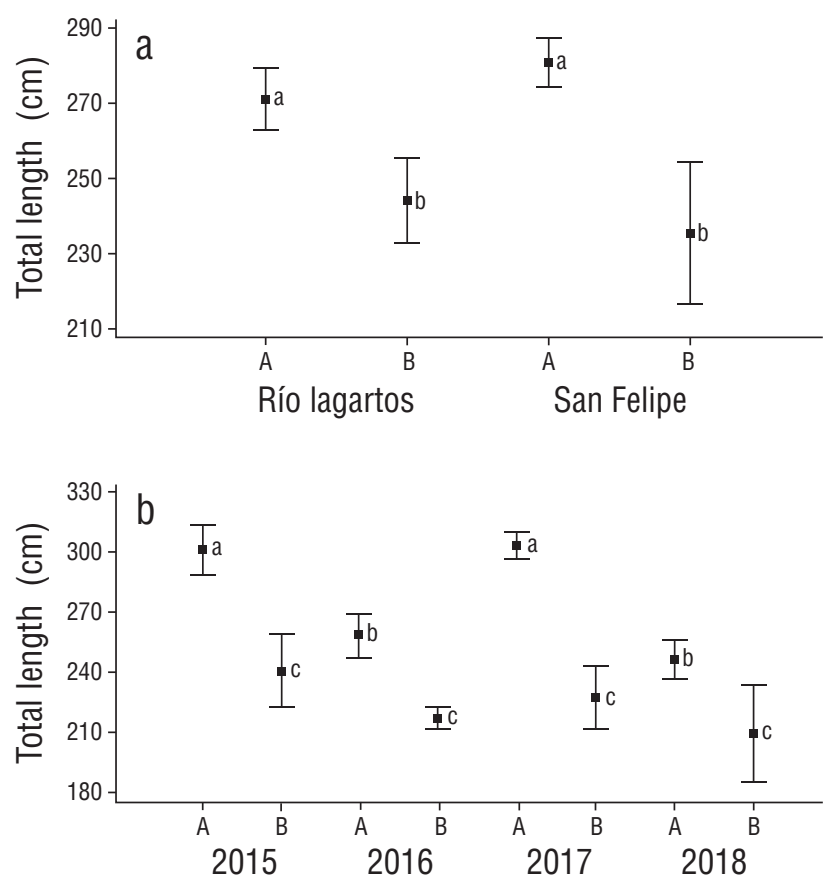

Figure 3. Mean length (cm) of Limulus polyphemus by location (a) and by year (b) in the 2015-2018 period. Homogeneous groups $(P>0.05)$ are indicated with the same letters for each treatment. A: before the octopus fishing season. B: during the octopus fishing season.

Figura 3. Longitud media (cm) de Limulus polyphemus por ubicación (a) y por año (b) en el periodo 2015-2018. Los grupos homogéneos $(P>0.05)$ se indican con las mismas letras para cada tratamiento. A: antes de la temporada de pesca de pulpo. B: durante la temporada de pesca de pulpo.

influencia negativa de la composición fisicoquímica del agua o de la composición sedimentológica en el reducido número de cacerolitas de mar encontradas.

En el presente estudio, además de observar una disminución en el número de individuos de L. polyphemus, la LT promedio de los individuos muestreados se redujo tras iniciada la temporada de pesca de pulpo. Los registros máximos alcanzaron un promedio global (2015-2018) de alrededor de $280 \mathrm{~mm}$ en San Felipe (antes de la temporada de pulpo) (Fig. 3a); la longitud promedio máxima fue de alrededor de $300 \mathrm{~mm}$ antes de la temporada de pulpo de 2017 (Fig. 3b). En contraste, los registros de la LT durante la temporada de pulpo no sobrepasaron los $260 \mathrm{~mm}$. En el conteo individual, los 2 ejemplares con mayor LT midieron 400 y $429 \mathrm{~mm}$, ambos recolectados en los muestreos antes de la temporada de pulpo en Río Lagartos en 2015 y 2017, respectivamente (datos no mostrados). Con respecto a estos registros, otros autores han registrado tallas similares en estudios previos en la península de Yucatán (Ortiz-León y Rosas-Correa 2011, Rosas-Correa y Ortiz-León 2012).

En L. polyphemus, como en otras especies, conforme aumenta la edad, aumentan el tamaño y el peso (Vijayakumar 
high percentage $(75 \%)$ of organisms tagged across 17 years migrated short distances (from 0 to $20 \mathrm{~km}$ ), compared to the $1.57 \%$ that migrated more than $100 \mathrm{~km}$. American horseshoe crabs migrate from shallow to deep waters, especially when they reach sexual maturity, but they return to the intertidal zone to spawn during high tide (Barlow et al. 1986, Smith et al. 2017). Because the RLBR is a spawning site for American horseshoe crabs (Sandoval-Gío et al. 2018), they would be expected to return to the intertidal zone to reproduce and spawn during full moons, assuming they did migrate to deep waters, but the numbers presented here show the opposite, at least for the seasons during which the present study was carried out. Hence, its use as octopus bait is concerning, since the number of American horseshoe crabs in a population will determine their distribution range; the more abundant the population, the greater the migration distances. The L. polyphemus population in the Yucatán Peninsula has been described, however, as not very abundant (Zaldívar-Rae et al. 2009, Smith et al. 2017).

In Yucatán, Octopus (O. maya and O. vulgaris) fishing is considered to be the most profitable fishing activity between August and December and, together with the red grouper Epinephelus morio, it represents $70 \%$ of total catches in this Mexican province (Munguía-Gil 2010). The commercial and exporta value for this fishery has increased in recent years, creating direct employment and substantial foreign currency incomes in southeast Mexico, but the activity could be unsustainable if it depends on affecting species with high-risk status such as L. polyphemus.

Currently, the reference framework known as DriverPressure-State-Impact-Response is useful to better under stand the cause-effect relationships between anthropogenic impact and the environmental components of an ecosystem (Gebremedhin et al. 2018). Therefore, fishing for $O$. maya and $O$. vulgaris could signify strong pressure derived from economic demand, which could change the status of L. polyphemus populations in the RLBR (Smith et al. 2017). We recommend that decision makers consider the data presented here for an analysis seeking efficient responses regarding the establishment of sustainable fishery management plans and conservation programs for the affected species in southeast Mexico.

In conclusion, during the study period, the relative abundance and average length of American horseshoe crabs sampled in 2 localities of the RLBR decreased after the start of the octopus season, in comparison with data recorded before the season began. Nevertheless, the analysis does not allow estimating the magnitude of the effects at the population level. This confirms our hypothesis: the significant decrease in the population and morphometry of $L$. polyphemus at the sampling sites suggests a possible negative influence related to its use as bait in the octopus fishery. However, we recommend comparing these data with population studies in other localities inhabited by the American horseshoe crab with no impact of illegal fishing. et al. 2000). Los resultados de la presente investigación muestran un decremento en la LT promedio después de iniciada la temporada de pulpo, que hace suponer que, en el contexto del abastecimiento ilícito de $L$. polyphemus para la pesquería de pulpo, los pescadores furtivos estarían capturando los ejemplares más grandes y, por lo tanto, más longevos para un mayor aprovechamiento de su carne disponible. La predilección en la pesca furtiva por organismos más grandes tendría varias implicaciones negativas para las cacerolitas de mar, especialmente en cuanto a la reproducción y el desove, ya que se ha observado que las cacerolitas de mar de mayor talla corresponden normalmente a hembras (Smith et al. 2017). Nosotros encontramos que en la mayoría de los muestreos había menos hembras durante la temporada de pulpo que antes de que ésta iniciara; no obstante, esta tendencia tuvo mayor énfasis en Río Lagartos, pero no en San Felipe (datos no mostrados).

Por otro lado, es importante recalcar que no puede descartarse que los cambios observados en los tamaños de las cacerolitas de mar pudieran deberse a otros factores de la historia de vida de la especie, por ejemplo, la migración, el reclutamiento, la época reproductiva o la mortalidad natural. Sin embargo, a la fecha los estudios biológicos en el área de estudio son insuficientes. Swan (2005) realizó un estudio sobre la migración de L. polyphemus de la costa atlántica norte de los EUA, y encontró que un alto porcentaje (75\%) de organismos marcados durante 17 años migró distancias cortas (de 0 a $20 \mathrm{~km}$ ), en comparación con un $1.57 \%$ que lo hizo por más de $100 \mathrm{~km}$. La cacerolita de mar migra desde aguas someras hasta más profundas, especialmente al alcanzar la madurez sexual, pero al llegar los ciclos de marea alta, regresa a la zona intermareal a desovar (Barlow et al. 1986, Smith et al. 2017). Siendo la RBRL un sitio de desove de las cacerolitas de mar (Sandoval-Gío et al. 2018), en las temporadas con luna llena se esperaría que regresen a la zona intermareal a reproducirse y a desovar, si es que hubiesen migrado a aguas profundas, pero los números aquí presentados demuestran lo contrario, al menos para las temporadas en las que se llevó a cabo el presente estudio. Por eso, el aspecto de su uso como carnada para pulpo es de preocupar, ya que el número de cacerolitas de mar en una población determinará el intervalo de su distribución, es decir, cuanto más abundante sea la población, mayores serán las distancias de su migración. Sin embargo, la población de L. polyphemus en la península de Yucatán se ha descrito como poco abundante (Zaldívar-Rae et al. 2009, Smith et al. 2017).

La captura de pulpo (O. maya y O. vulgaris) se considera la actividad pesquera productiva más redituable en Yucatán entre los meses de agosto a diciembre y, junto con la captura del mero Epinephelus morio, representa el 70\% de la pesca en esta provincia mexicana (Munguía-Gil 2010). El valor comercial y de exportación de esta pesquería ha aumentado en los últimos años, lo cual ha generado empleos directos y sustanciosas divisas en el sureste de México, pero esta actividad podría no ser del todo sostenible si se basa en la 
The results presented here should be taken with caution, given the low methodological replication. Therefore, more extensive research that considers other biological factors, such as migration, life cycle, and mortality, of the mex in the RLBR, coupled with socioeconomic studies, could more solidly elucidate the potential risk of the octopus fishery on the limulus populations in this protected natural area. Unlike the Atlantic coast of the USA, where environmental education programs for the preservation of American horseshoe crabs have been historically more frequent (Walls et al. 2002), in Mexico events of this nature are inexistent. Transdisciplinary research is clearly needed to channel efforts leading to the conservation of this species in risk areas.

\section{ACKNOWLEDGMents}

This study was funded by the National Council for Science and Technology (CONACYT, Mexico), project no. PDCPN 2015-1097. We thank 2 anonymous reviewers for their objective criticism, which helped optimize this contribution.

English translation by Claudia Michel-Villalobos.

\section{REFERENCES}

Barlow RB Jr, Powers MK, Howard H, Kass L. 1986. Migration of Limulus for mating: relation to lunar phase, tide height, and sunlight. Biol Bull. 171(2):310-329. https://doi.org/10.2307/1541674

Bianchini ML, Sorensen PW, Winn HE. 1981. The use of Horseshoe crabs as eel bait. J World Maric Soc. 12(2):127-129. https://doi.org/10.1111/j.1749-7345.1981.tb00286.x

Botton ML, Ropes JW. 1987. The Horseshoe Crab, Limulus polyphemus, Fishery and Resource in the United States. Mar Fish Rev. 49(3):57-61.

[CONAGUA] Comisión Nacional del Agua (Mexico). 2017. Servicio Meteorológico Nacional/Comisión Nacional del Agua. Normales Climatológicas por Estado. Mexico City: Servicio Meteorológico Nacional; accessed 2017 Sep 11. https://smn. conagua.gob.mx/es/informacion-climatologica-porestado?estado=yuc.

[DOF] Diario Oficial de la Federación. 2010. NORMA Oficial Mexicana NOM-059-SEMARNAT-2010, Protección ambientalEspecies nativas de México de flora y fauna silvestresCategorías de riesgo y especificaciones para su inclusión, exclusión o cambio-Lista de especies en riesgo. Mexico City: Secretaría de Medio Ambiente y Recursos Naturales.

Flores-Nava A, Villanueva-García-Benítez J, Vidal-Martínez VM, Olvera-Novoa MA, Alonzo-Marrufo ER, Arreguín-Sánchez F, Poot-López GR, Alonso-Alemán M, Maldonado-Repetto A. 2016. Diagnóstico de los sectores de la pesca y la acuacultura en el estado de Yucatán. Mérida (México): Food and Agriculture Organization of the United Nations (FAO). 122 p. Project No. UTF/MEX/117.

Folk RL. 1966. A review of grain-size parameters. Sedimentology. 6(2):73-93. https://doi.org/10.1111/j.1365-3091.1966.tb01572.x

García E. 2004. Modificaciones al Sistema de Clasificación Climática de Köppen. Serie Libros No. 6. México: Universidad Nacional Autónoma de México, Instituto de Geografía.

García-Bielma MA. 2011. La conservación del mesh (Limulus polyphemus) en la Laguna de Términos. Acalán. 48:24-30. afectación de una especie con un estatus de riesgo muy alto, como lo es L. polyphemus.

Actualmente, el marco de referencia denominado Conductores-Presión-Estado-Impacto-Respuestas es de utilidad para comprender mejor las relaciones causa-efecto entre el impacto antropogénico y los componentes ambientales de un ecosistema (Gebremedhin et al. 2018). En este contexto, la pesca de O. maya y O. vulgaris podría significar una fuerte presión derivada de la demanda económica, lo que podría cambiar el estado de las poblaciones de L. polyphemus en la RBRL (Smith et al. 2017). Se recomienda tomar en cuenta los datos aquí presentados para llevar a cabo un análisis entre tomadores de decisiones, con respuestas eficientes con respecto al establecimiento de planes de manejo pesquero sostenible y a los programas de conservación de las especies involucradas en el sureste de México.

Se concluye que en el periodo evaluado ocurrió una disminución en la abundancia relativa y la longitud promedio de las cacerolitas de mar muestreadas en 2 localidades de la RBRL después del inicio de la temporada de pulpo, con respecto a los datos registrados antes de que esta temporada iniciara. Sin embargo, el análisis no permite calcular la magnitud de la afectación a nivel poblacional. Esto confirma la hipótesis planteada inicialmente: la disminución significativa poblacional y morfométrica de ejemplares de L. polyphemus en los sitios muestreados pueden sugerir una posible influencia negativa relacionada a su uso como carnada para la pesca de pulpo. No obstante, se recomienda contrastar estos datos con estudios poblacionales en otras localidades donde habite la cacerolita de mar y no haya impacto de la pesca ilegal.

Los resultados aquí presentados deben tomarse con reserva, dada la reducida replicación metodológica, por lo que investigaciones más exhaustivas que asocien otros factores biológicos, como la migración, el ciclo de vida y la mortalidad, del mex en la RBRL, aunado a estudios de carácter socioeconómico, podrían contribuir a dilucidar de forma más sólida el riesgo potencial de la pesquería de pulpo sobre las poblaciones del límulo en esta área natural protegida. A diferencia de lo que ocurre en localidades de la costa atlántica de los EUA, donde los programas de educación ambiental para la preservación de la cacerolita de mar han sido históricamente más frecuentes (Walls et al. 2002), en México los eventos de esta índole están ausentes. Es claro que se requiere investigación transdisciplinaria para encauzar esfuerzos que conlleven a la conservación de esta especie en zonas de riesgo.

\section{Agradecimientos}

El presente estudio fue financiado por el Consejo Nacional de Ciencia y Tecnología (CONACYT, México), proyecto PDCPN 2015-1097. Se agradece la crítica objetiva de 2 revisores anónimos que optimizaron esta contribución. 
Gebremedhin S, Getahun A, Anteneh W, Bruneel S, Goethals P. 2018. A drivers-pressure-state-impact-responses framework to support the sustainability of fish and fisheries in Lake Tana, Ethiopia. Sustainability. 10(8):29-57. https://doi.org/10.3390/su10082957

Gómez-Aguirre S. 1993. Cacerolita de mar (Limulus polyphemus L.) en la Península de Yucatán. In: SalazarVallejo SI, González NE (eds.), Biodiversidad Marina y Costera de México. Chetumal (Quintana Roo, Mexico): Centro de Investigaciones de Quintana Roo. p. 650-659.

Gómez-Aguirre S. 1994. Contribución a la Demografía de Limulus polyphemus L. (Arthropoda Merostomata) en la Península de Yucatán. In: Álvarez-Silva C, Figueroa-Torres MG, GómezAguirre S, Esquivel-Herrera A (eds.), Serie Grandes Temas de la Hidrobiología: Los Sistemas Litorales. No 2. México: Universidad Autónoma Metropolitana. p. 69-75.

Gómez-Aguirre S, Yáñez-Martínez A. 1995. Evaluación estacional de las poblaciones de Limulus polyphemus L. en el norte de la Península de Yucatán (1994-1995). Rev Soc Mex Hist Nat. 46:49-54.

Jackson NL, Nordstrom KF, Eliot I, Masselink G. 2002. 'Low energy' sandy beaches in marine and estuarine environments: a review. Geomorphology. 48(1-3):147-162. https://doi.org/10.1016/s0169-555x(02)00179-4

Jurado-Molina JA. 2010. A Bayesian framework with implementation error to improve the management of the red octopus (Octopus maya) fishery off the Yucatán Peninsula $=$ Enfoque bayesiano con error de implementación para mejorar el manejo de la pesquería de pulpo rojo (Octopus maya) en la Península de Yucatán. Cienc Mar. 36(1):1-14. https://doi.org/10.7773/cm.v36i1.1627

Kreamer G, Michels S. 2009. History of horseshoe crab harvest on Delaware Bay. In: Tanacredi JT, Botton ML, Smith D (eds.), Biology and Conservation of Horseshoe Crabs. New York (NY): Springer. p. 299-313. https://doi.org/10.1007/978-0-387-89959-6 19

Markaida U, Méndez-Loeza I, Rodríguez-Domínguez A. 2019. Capture efficiency of artificial lures in baited lines for Mayan octopus, Octopus maya, fishery in Campeche, Mexico. Mar Fish Rev. 81(1):53-60. https://doi.org/10.7755/mfr.81.1.3

Munguía-Gil A. 2010. El futuro económico de la pesca. In: Durán R, Méndez M (eds.), Biodiversidad y Desarrollo Humano en Yucatán. Yucatán (Mexico): Centro de Investigación Científica de Yucatán. p. 112-115.

Novitsky TJ. 1991. Discovery to commercialization: the blood of the horseshoe crab. Oceanus. 27:13-18.

Ortiz-León HJ, Rosas-Correa CO. 2011. Cacerolita de mar. In: Pozo C, Armijo-Canto N, Caimé S (eds.), Riqueza Biológica de Quintana Roo: un Análisis para su Conservación. Mexico City: Comisión Nacional para el Conocimiento y Uso de la Biodiversidad. p. 114-119.

Rosas C, Gallardo P, Mascaró M, Caamal-Monsreal C, Pascual C. 2014. Octopus maya. In: Iglesias J, Fuentes L, Villanueva R (eds.), Cephalopod Culture. Netherlands: Springer. p. 383-396.

Rosas-Correa CO, Ortiz-León HJ. 2012. Cacerolita de Mar Limulus polyphemus en Holbox, Quintana Roo. México: Dinámica Poblacional. Germany: Editorial Académica Española. 52 p.

Rudkin DM, Young GA. 2009. Horseshoe crabs: An ancient ancestry revealed. In: Tanacredi JT, Botton ML, Smith D (eds.), Biology and Conservation of Horseshoe Crabs. New York (NY): Springer. pp. 25-44.
Salas S, Bjørkan M, Bobadilla F, Cabrera MA. 2011. Addressing vulnerability: coping strategies of fishing communities in Yucatan, Mexico. In: Jentoft JS, Eide A. (eds.), Poverty Mosaics: Realities and Prospects in Small-Scale Fisheries. Dordrecht (Netherlands): Spinger. p. 195-220. https://doi.org/10.1007/978-94-007-1582-0_10

Sauer WHH, Gleadall IG, Downey-Breedt N, Doubleday Z, Gillespie G, Haimovici M, Ibáñez CM, Katugin ON, Leporati S, Lipinski MR, et al. 2019. World octopus fisheries. Rev Fish Sci Aquac. https://doi.org/10.1080/23308249.2019.1680603

Sandoval-Gío JJ, Ortiz-León HJ, Rosas-Correa CO, Correa-Valdez, TJ. 2016. Disminución de poblaciones de cacerolita de mar Limulus polyphemus en la reserva Ría Lagartos, Yucatán: una perspectiva socioeconómica. $21^{\circ}$ Encuentro Nacional sobre Desarrollo Regional en México; Mérida, Yucatán (México); 1518 Nov 2016. Mexico: Asociación Mexicana de Ciencias para el Desarrollo Regional. p. 1-2.

Sandoval-Gío JJ, Zamora-Bustillos R, Avilés-Ramírez GA, Ortiz-León HJ, Rosas-Correa CO 2018. First report of a spawning site of Limulus polyphemus at Ría Lagartos Biosphere Reserve, Yucatan, Mexico = Primer reporte de un sitio de desove de Limulus polyphemus en la Reserva de la Biósfera Ría Lagartos, Yucatán, México. Revista Bio Ciencias. 5(1):1-8. https://doi.org/10.15741/revbio.05.2018.05

Smith DR, Beekey MA, Brockmann HJ, King TL, Millard MJ, Zaldívar-Rae JA. 2016. Limulus polyphemus. The IUCN Red List of Threatened Species 2016: eT11987A80159830. https://dx.doi.org/10.2305/IUCN.UK.2016-1.RLTS. T11987A80159830.en

Smith DR, Brockmann HJ, Beekey MA, King TL, Millard MJ, Zaldivar-Rae J. 2017. Conservation status of the American horseshoe crab, (Limulus polyphemus): a regional assessment. Rev Fish Biol Fish. 27:135-175. https://dx.doi.org/10.1007/s11160-016-9461-y

Swan BL. 2005. Migrations of adult horseshoe crabs, Limulus polyphemus, in the Middle Atlantic Bight: A 17-year tagging study. Estuaries. 28:28-40. https://doi.org/10.1007/bf02732751

Velázquez-Abunader I, Salas S, Cabrera MA. 2013. Differential catchability by zone, fleet, and size: the case of the red Octopus (Octopus maya) and common octopus (Octopus vulgaris) fishery in Yucatan, Mexico. J Shellfish R. 32(3):845-854. http://dx.doi.org/10.2983/035.032.0328

Vijayakumar R, Das S, Chatterji A, Parulekar AH. 2000. Morphometric characteristics in the horseshoe crab Tachypleus gigas (Arthropoda: Merostomata). Indian J Geo-Mar Sci. 29:333-335.

Walls EA, Berkson J, Smith SA. 2002. The horseshoe crab, Limulus polyphemus: 200 million years of existence, 100 years of study. Rev Fish Sci Aquac. 10(1):30-73. https://doi.org/10.1080/20026491051677

Zaldívar-Rae J, Sapién-Silva RE, Rosales-Raya M, Brockmann HJ. 2009. American Horseshoe Crabs, Limulus polyphemus, in Mexico: Open Possibilities. In: Tanacredi JT, Botton ML, Smith D (eds.), Biology and Conservation of Horseshoe Crabs. New York (NY): Springer. p. 97-113. https://doi.org/10.1007/978-0-387-89959-6_6

Received March 2019, accepted March 2020. 